\title{
RNP Granule Formation: Lessons from P-Bodies and Stress Granules
}

\author{
Giulia Ada Corbet ${ }^{1}$ AND Roy ParkeR ${ }^{1,2}$ \\ ${ }^{1}$ Department of Biochemistry, \\ ${ }^{2}$ Howard Hughes Medical Institute, University of Colorado at Boulder, Boulder, Colorado 80309, USA \\ Correspondence: roy.parker@colorado.edu
}

\begin{abstract}
It is now clear that cells form a wide collection of large RNA-protein assemblies, referred to as RNP granules. RNP granules exist in bacterial cells and can be found in both the cytosol and nucleus of eukaryotic cells. Recent approaches have begun to define the RNA and protein composition of a number of RNP granules. Herein, we review the composition and assembly of RNP granules, as well as how RNPs are targeted to RNP granules using stress granules and P-bodies as model systems. Taken together, these reveal that RNP granules form through the summative effects of a combination of protein-protein, protein-RNA, and RNA-RNA interactions. Similarly, the partitioning of individual RNPs into stress granules is determined by the combinatorial effects of multiple elements. Thus, RNP granules are assemblies generally dominated by combinatorial effects, thereby providing rich opportunities for biological regulation.
\end{abstract}

Ribonucleoprotein (RNP) granules are a diverse set of biomolecular assemblies of RNA and protein that form within cells. RNP granules in the nucleus, such as Cajal bodies, the nucleolus, and paraspeckles, regulate various steps of RNA and RNP processing (Table 1; Trinkle-Mulcahy and Sleeman 2017; Fox et al. 2018). Cytoplasmic granules, such as P-bodies and stress granules, may regulate RNA translation, RNA degradation, signaling pathways, and stress responses (Sheth and Parker 2003; Kedersha et al. 2013; Protter and Parker 2016; Samir et al. 2019). RNP transport granules in neurons and myogranules in skeletal muscle are thought to facilitate RNA transport and localized translation (Kiebler and Bassell 2006; Vogler et al. 2018). Furthermore, germ granules, such as Caenorhabditis elegans P-granules and Drosophila polar bodies, form in the germline during development, contain maternally encoded mRNAs, and help specify germ cell fate (Voronina et al. 2011; Wang and Seydoux 2014; Trcek and Lehmann 2019).

RNP granules are also found in bacteria. In Caulobacter, bacterial RNP bodies (BR-bodies) form under stress and can be considered similar to eukaryotic stress granules (Al-Husini et al. 2018). It is likely only a matter of time before more RNP granules are discovered in bacteria.

Aberrant RNP granules are also pathological hallmarks of numerous neurodegenerative and neuromuscular diseases, including amyotrophic lateral sclerosis (ALS), frontotemporal lobar degeneration (FTLD), and inclusion body myopathy (Arai et al. 2006; Neumann et al. 2006; Weihl et al. 2008; Dickson et al. 2011). These aggregates often contain many of the same components that are found in canonical RNP granules, such as stress granules and splicing speckles, suggesting that aberrant granules may arise from canonical granules and thereby contribute to neurodegenerative diseases (Taylor et al. 2016; Hsieh et al. 2019; Wolozin and Ivanov 2019).

An unanswered question is how RNP granules assemble, and what interactions allow for multiple distinct RNP granules to exist in cells at any given time. Herein, we review the composition, assembly, and how RNPs are targeted to RNP granules using stress granules (SGs) and P-bodies (PBs) as model systems to understand these issues.

\section{RNP GRANULE COMPOSITION}

\section{Proteins in RNP Granules}

Three types of approaches have been used to identify components of RNP granules (Fig. 1). First, and sometimes the initial identification of the granule, has been the identification of locally concentrated proteins by immunofluorescence or by the tagging of proteins with green fluorescent protein (GFP). More complete descriptions of the proteins in RNP granules has come from mass spectroscopy of RNP granules purified by differential centrifugation, with or without immunopurification, or by using particle sorting to fractionate granules (Jain et al. 2016; Hubstenberger et al. 2017). A third approach has been to use proximity labeling approaches such as Bio-ID or APEX labeling (Markmiller et al. 2018; Youn et al. 2018), although such proximity labeling approaches are unable to distinguish between interacting proteins within the granule or outside the granule, which can be an issue because even proteins that are highly concentrated in gran-

(C) 2019 Corbet and Parker. This article is distributed under the terms of the Creative Commons Attribution-NonCommercial License, which permits reuse and redistribution, except for commercial purposes, provided that the original author and source are credited. 
Table 1. Overview of select ribonucleoprotein (RNP) granules function and composition

\begin{tabular}{|c|c|c|c|c|c|}
\hline RNP granule & $\begin{array}{l}\text { Cell type/ } \\
\text { modulators }\end{array}$ & Function & Protein composition & RNA composition & References \\
\hline Nucleolus & $\begin{array}{l}\text { Found in all cell } \\
\text { types during } \\
\text { interphase }\end{array}$ & $\begin{array}{l}\text { Site of rRNA } \\
\text { transcription, } \\
\text { pre-rRNA } \\
\text { processing, } \\
\text { ribosome } \\
\text { assembly }\end{array}$ & $\begin{array}{l}\text { snRNPs, ribosomal } \\
\text { proteins, and } \\
\text { ribosome biogenesis } \\
\text { factors: RNA } \\
\text { polymerase I, DNA } \\
\text { topoisomerase, } \\
\text { fibrillarin, nucleolin, } \\
\text { p52; RNA- } \\
\text { modifying enzymes }\end{array}$ & snoRNAs, rRNAs & $\begin{array}{l}\text { Yasuzumi et al. 1958; } \\
\text { Chamberland and } \\
\text { Lafontaine 1993; } \\
\text { Scheer et al. 1993; } \\
\text { Mélèse and Xue 1995; } \\
\text { Maden and Hughes } \\
\text { 1997; Dundr and } \\
\text { Olson 1998; Olson } \\
\text { et al. 2000; Fatica and } \\
\text { Tollervey 2002; } \\
\text { Desterro et al. } 2003\end{array}$ \\
\hline Cajal body & All cell types & $\begin{array}{l}\text { snRNP assembly, } \\
\text { processing }\end{array}$ & $\begin{array}{l}\text { coilin, Sm proteins, } \\
\text { SMN, NIOPP140, } \\
\text { snRNPs }\end{array}$ & $\begin{array}{l}\text { snRNAs, scaRNAs, } \\
\text { snoRNAs }\end{array}$ & $\begin{array}{l}\text { Gall et al. 1999; } \\
\text { Narayanan et al. 1999; } \\
\text { Sleeman and Lamond } \\
\text { 1999; Hebert and } \\
\text { Matera 2000; Carmo- } \\
\text { Fonseca 2002; } \\
\text { Darzacq et al. 2002; } \\
\text { Verheggen et al. 2002; } \\
\text { Schaffert et al. 2004; } \\
\text { Cioce and Lamond } \\
\text { 2005; Morris 2008; } \\
\text { Staněk et al. 2008; } \\
\text { Shaw et al. 2014; } \\
\text { Hebert and Poole } \\
\text { 2016; Love et al. 2016; } \\
\text { Trinkle-Mulcahy and } \\
\text { Sleeman 2017 }\end{array}$ \\
\hline Paraspeckle & $\begin{array}{l}\text { All cell types, } \\
\text { increase in stress }\end{array}$ & Unknown & $\begin{array}{l}\text { RNA-binding proteins: } \\
\text { PSPC1, p54nrb, } \\
\text { SFPQ, RBM14, } \\
\text { CPSF6 }\end{array}$ & $\begin{array}{l}\text { NEAT1 lncRNA, } \\
\text { hyperedited RNAs }\end{array}$ & $\begin{array}{l}\text { Prasanth et al. 2005; } \\
\text { Bond and Fox 2009; } \\
\text { Clemson et al. 2009; } \\
\text { Fox and Lamond } \\
\text { 2010; Nakagawa et al. } \\
\text { 2011; Naganuma et al. } \\
\text { 2012; Naganuma and } \\
\text { Hirose 2013; Imamura } \\
\text { et al. 2014; Fox et al. } \\
\text { 2018 }\end{array}$ \\
\hline P-bodies & $\begin{array}{l}\text { Constitutive but } \\
\text { increase in stress }\end{array}$ & $\begin{array}{l}\text { Translation } \\
\text { regulation, RNA } \\
\text { storage, } \\
\text { degradation }\end{array}$ & $\begin{array}{l}\text { mRNA decapping } \\
\text { enzymes, } \\
\text { exonucleases, RNA- } \\
\text { binding proteins, } \\
\text { NMD factors, } \\
\text { translation } \\
\text { repressors, RNA } \\
\text { helicases }\end{array}$ & $\begin{array}{l}\text { Enriched for } \\
\text { nontranslating } \\
\text { mRNAs, biased for } \\
\text { AU-rich RNAs, } \\
\text { RNA composition } \\
\text { similar to stress } \\
\text { granules under stress, } \\
\text { enriched for RNAs } \\
\text { with short poly(A) } \\
\text { tails }\end{array}$ & $\begin{array}{l}\text { Schwartz and Parker } \\
\text { 1999; Sheth and Parker } \\
\text { 2003, 2006; Decker } \\
\text { et al. 2007; Eulalio } \\
\text { et al. 2007; Teixeira } \\
\text { and Parker 2007; } \\
\text { Buchan et al. 2008; } \\
\text { Pilkington and Parker } \\
\text { 2008; Hubstenberger } \\
\text { et al. 2017; Courel } \\
\text { et al. 2019; Matheny } \\
\text { et al. } 2019\end{array}$ \\
\hline Stress granules & $\begin{array}{l}\text { Induced by stress } \\
\text { such as viral } \\
\text { infection, heat/ } \\
\text { cold shock, } \\
\text { oxidative stress, } \\
\text { starvation }\end{array}$ & $\begin{array}{l}\text { Unknown, } \\
\text { hypothesized to } \\
\text { regulate } \\
\text { translation, RNA } \\
\text { stability, cell } \\
\text { survival, cell } \\
\text { signaling }\end{array}$ & $\begin{array}{l}\text { RNA-binding proteins: } \\
\text { G3BP1, UBAP2L, } \\
\text { PABPC1, TIA-1, } \\
\text { IDR-containing } \\
\text { proteins, RNA } \\
\text { helicases, translation } \\
\text { factors }\end{array}$ & $\begin{array}{l}\text { Enriched for longer } \\
\text { and poorly translated } \\
\text { mRNAs }\end{array}$ & $\begin{array}{l}\text { Kedersha et al. 1999, } \\
\text { 2000, 2005, 2013, } \\
\text { 2016; Gilks et al. } \\
\text { 2004; Buchan and } \\
\text { Parker 2009; Hofmann } \\
\text { et al. 2012; Buchan } \\
\text { et al. 2013; Jain et al. } \\
\text { 2016; Wheeler et al. } \\
\text { 2016; Khong et al. } \\
\text { 2017; Namkoong et al. } \\
\text { 2018; Protter et al. } \\
\text { 2018; Matheny et al. } \\
\text { 2019; Moon et al. } \\
\text { 2019, 2020; Cirillo } \\
\text { et al. 2020 }\end{array}$ \\
\hline
\end{tabular}


Table 1. Continued

\begin{tabular}{|c|c|c|c|c|c|}
\hline RNP granule & $\begin{array}{l}\text { Cell type/ } \\
\text { modulators }\end{array}$ & Function & Protein composition & RNA composition & References \\
\hline P-granules & $\begin{array}{l}\text { Caenorhabditis } \\
\text { elegans germline }\end{array}$ & $\begin{array}{l}\text { Germ cell fate } \\
\text { specification, } \\
\text { RNA silencing }\end{array}$ & $\begin{array}{l}\text { RNA-binding proteins: } \\
\text { PGL-1, PGL-3, } \\
\text { MEG-3, LAF-1, } \\
\text { IDR-containing } \\
\text { proteins, RNA } \\
\text { helicases }\end{array}$ & $\begin{array}{l}\text { Maternal mRNAs, } \\
\text { poorly translated } \\
\text { mRNAs }\end{array}$ & $\begin{array}{l}\text { Voronina et al. 2012; } \\
\text { Seydoux 2018; } \\
\text { Ouyang et al. 2019; } \\
\text { Putnam et al. 2019; } \\
\text { Lee et al. } 2020\end{array}$ \\
\hline Polar granules & Drosophila & $\begin{array}{l}\text { Germ cell fate, } \\
\text { RNA } \\
\text { segregation }\end{array}$ & $\begin{array}{l}\text { RNA-binding proteins: } \\
\text { Vasa, Tudor, eIF4A, } \\
\text { Aubergine, ME31B, } \\
\text { TER94, Oskar }\end{array}$ & $\begin{array}{l}\text { Nanos, cyclin B, polar } \\
\text { granule component, } \\
\text { oskar mRNAs }\end{array}$ & $\begin{array}{l}\text { Mahowald 1971; Hay } \\
\text { et al. 1988; Ephrussi } \\
\text { and Lehmann 1992; } \\
\text { Nakamura et al. 1996; } \\
\text { Ferrandon et al. 1997; } \\
\text { Thomson and Lasko } \\
\text { 2004; Arkov et al. } \\
\text { 2006; Jones and } \\
\text { Macdonald 2007; } \\
\text { Vanzo et al. 2007; } \\
\text { Thomson et al. 2008; } \\
\text { Little et al. 2015 }\end{array}$ \\
\hline Myogranules & $\begin{array}{l}\text { Regenerating } \\
\text { skeletal muscle }\end{array}$ & $\begin{array}{l}\text { Unknown, } \\
\text { hypothesized to } \\
\text { facilitate } \\
\text { localized } \\
\text { translation }\end{array}$ & $\begin{array}{l}\text { RNA-binding proteins: } \\
\text { TDP-43, FMRP; } \\
\text { IDR-containing } \\
\text { proteins }\end{array}$ & $\begin{array}{l}\text { Unknown, } \\
\text { hypothesized to be } \\
\text { long, sarcomeric } \\
\text { mRNAs }\end{array}$ & Vogler et al. 2018 \\
\hline $\begin{array}{l}\text { C9ORF72 } \\
\text { RNA foci }\end{array}$ & $\begin{array}{l}\text { Neurons, glia, } \\
\text { fibroblasts }\end{array}$ & Aberrant & $\begin{array}{l}\text { Hypothesized to } \\
\text { contain RNA- } \\
\text { binding proteins }\end{array}$ & $\begin{array}{l}C 9 O R F 72 \mathrm{G}_{4} \mathrm{C}_{2} \\
\text { repeat, potentially } \\
\text { entire transcript and/ } \\
\text { or other RNA species }\end{array}$ & $\begin{array}{l}\text { DeJesus-Hernandez } \\
\text { et al. 2011; Fratta et al. } \\
\text { 2012; Almeida et al. } \\
\text { 2013; Gendron et al. } \\
\text { 2013; Mori et al. 2013; } \\
\text { Kumar et al. 2017; } \\
\text { Česnik et al. } 2019\end{array}$ \\
\hline $\begin{array}{l}\text { Myotonic } \\
\text { dystrophy } \\
\text { type } 1 \\
\text { (DM1) } \\
\text { granules }\end{array}$ & $\begin{array}{l}\text { Skeletal muscle, } \\
\text { neurons }\end{array}$ & Aberrant & MBNL1, MBNL2 & $D M P K$ transcript & $\begin{array}{l}\text { Taneja et al. 1995; Wang } \\
\text { et al. 1995; Timchenko } \\
\text { et al. 1996; Davis et al. } \\
\text { 1997; Jiang et al. } 2004\end{array}$ \\
\hline $\begin{array}{l}\text { Bacterial RNP } \\
\text { bodies (BR- } \\
\text { bodies) }\end{array}$ & $\begin{array}{l}\text { Caulobacter, other } \\
\alpha \text {-proteobacteria } \\
\text { form in stress }\end{array}$ & $\begin{array}{l}\text { RNA degradation, } \\
\text { rRNA } \\
\text { processing }\end{array}$ & $\begin{array}{l}\text { RNA degradeosome } \\
\text { proteins: RNase E, } \\
\text { Aconitase, RhlB }\end{array}$ & Nontranslating RNAs & Al-Husini et al. 2018 \\
\hline
\end{tabular}

(rRNA) Ribosomal RNA, (snRNP) small nuclear ribonucleoprotein, (snoRNA) small nucleolar RNA, (snRNA) small nuclear RNA, (scaRNA) small Cajal body-specific RNA, (lncRNA) long noncoding RNA, (mRNA) messenger RNA, (NMD) nonsense-mediated decay.

ules can have a majority of molecules outside the granule in the cell (Wheeler et al. 2017). Taken together, these approaches have revealed several features of RNP granule proteomes.

RNP granules contain three types of RNA-binding proteins (RBPs). First, there are RBPs that contribute to the assembly of the granule by providing protein-based crosslinks between different RNAs or by forming a proteinbased assembly. Second, there are RBPs that bind to RNAs resident to a granule and as such are simply carried into the granule by the RNAs. Third, there can be RBPs, such as YB-1 (Bounedjah et al. 2014) and eIF4A for stress granules (Tauber et al. 2020), that bind to RNA and compete for RNA-RNA interactions that would other promote RNP granule formation.

Some RBPs are found in more than one RNP granule. This can be understood for RBPs that bind RNAs and are carried into granules. However, RBPs that play a role in the formation of a specific granule are generally only found in that granule. For example, G3BP1 or Edc3, which are important for $\mathrm{SG}$ or $\mathrm{PB}$ formation (Tourrière et al. 2003; Decker et al. 2007), respectively, are only found in those granules (Kedersha et al. 2005; Decker et al. 2007). Furthermore, coilin, which is essential for Cajal body (CB) formation, is found specifically within CBs (Raška et al. 1991; Sleeman et al. 2003).

RNP granules can also contain other types of proteins. For example, stress granules are known to contain a number of proteins involved in cellular signaling pathways and SG formation can influence cell signaling (Kedersha et al. 2013). Similarly, SGs can contain proteins involved in metabolism (Jain et al. 2016; Bergovich et al. 2020). Moreover, the nucleolus contains a wide variety of proteins involved in a number of physiological process, such as dealing with misfolded proteins (Boisvert et al. 2007; Frottin et al. 2019). Taken together, the compositional studies suggest that cells have taken advantage of the formation of RNP granules to create localized concentrations of proteins involved in various processes, thereby increasing their effectiveness.

Although multiple RNP granules have been described as having very complex proteomes, the composition of RNP granules may often be much simpler. For example, yeast and mammalian PBs have been described to have more 


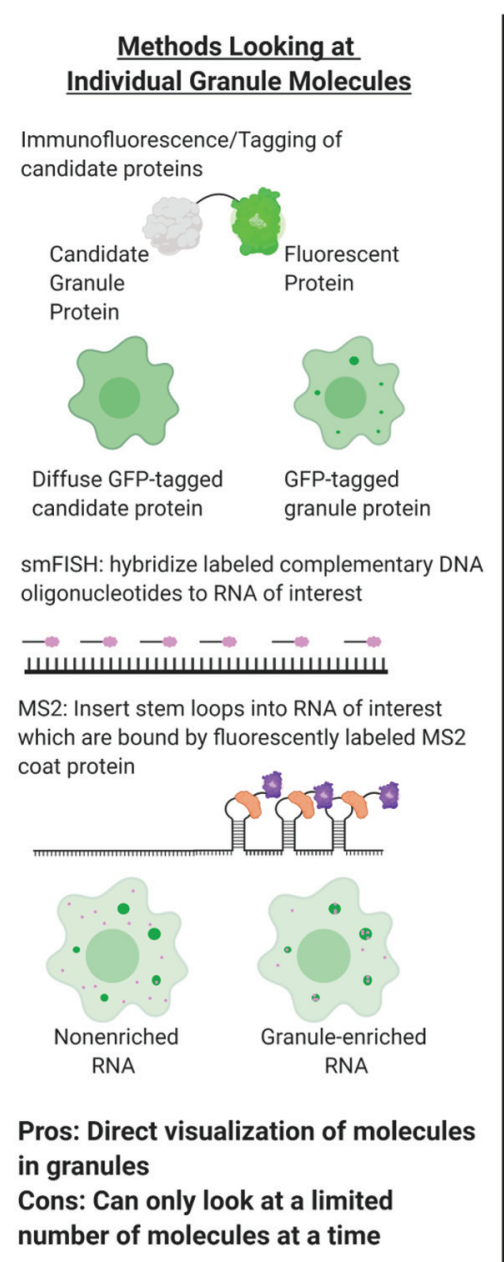

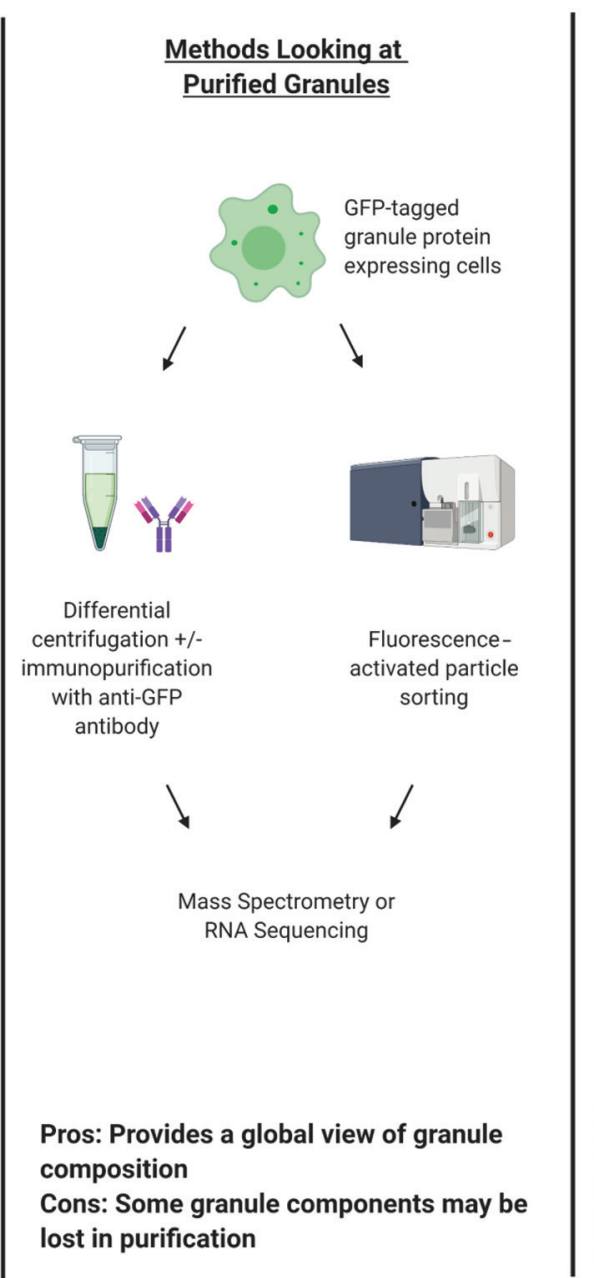

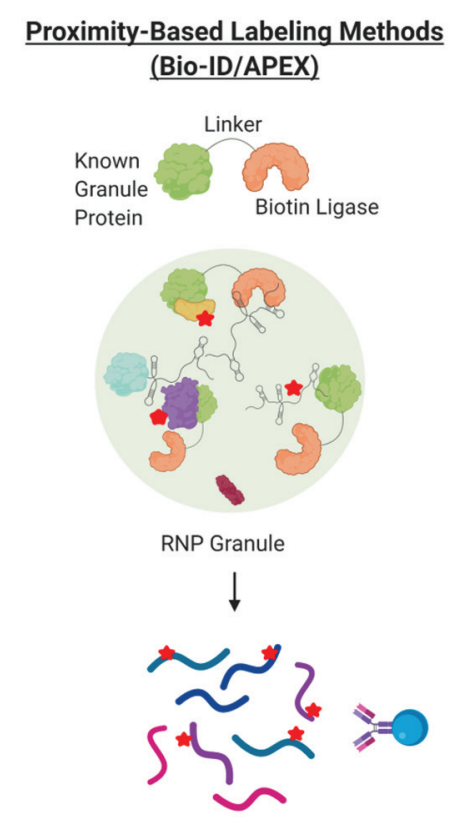

Purification of botinylated peptides or RNAs

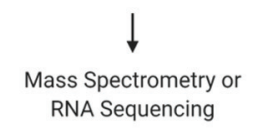

Pros: Identifies interacting partners of known granule proteins Cons: Unable to distinguish between interactions occurring inside a granule versus outside

Figure 1. Overview of the three major approaches to determining the protein or RNA composition of ribonucleoprotein (RNP) granules. One approach involves probing for individual proteins or RNAs by fluorescence imaging methods (left). A second approach involves purifying RNP granules, followed by RNA sequencing or mass spectrometry to determine the RNA or protein compositions, respectively (middle). The third approach relies on tagging RNAs or proteins that interact with known granule proteins, followed by purification of tagged molecules and RNA sequencing or mass spectrometry (right).

than 50 or 100 different proteins resident to them, respectively (Hubstenberger et al. 2017). However, a quantitative analysis revealed that only 14 proteins are highly concentrated within yeast PBs, and the other approximately 36 proteins are present at low amounts (Xing et al. 2020). This is significant because $300-500$ different proteins have been identified in SGs (Jain et al. 2016) and 200 proteins have been identified in the nucleolus (Thul et al. 2017). An important area of future research will be quantitative analyses of the abundance of these components to determine the primary constituents of any given RNP granule.

\section{RNAs in RNP Granules}

The RNAs present in RNP granules have been identified by three general approaches (Fig. 1). In one case, individual RNAs are examined by single-molecule fluorescence in situ hybridization (smFISH) or by tagging the RNAs with a fluorescent system such as MS2. A second approach has been to purify RNP granules and then sequence the copurifying RNAs (Hubstenberger et al. 2017; Khong et al. 2017; Namkoong et al. 2018). A third approach is to identify RNAs that interact with a key component of an RNP granule, inferring that this will identify RNA present in that assembly. This latter approach, followed by smFISH to validate the inferred partitioning, has worked well for the identification of mRNAs in C. elegans P-granules (Lee et al. 2020). These experiments have revealed the following features of RNP granules.

First, as inferred from their definition, every RNP granule contains a set of RNAs, although they can vary between different RNP granules. For example, both SG and PBs in the cytosol are made up of a wide distribution of nontranslating messenger RNAs (mRNAs) and long noncoding RNAs (lncRNAs) (Hubstenberger et al. 2017; Khong et al. 2017). Cajal bodies contain a population of small Cajal body-specific RNAs (scaRNAs), small nucleolar RNAs (snoRNAs), and small nuclear RNAs (snRNAs) (Darzacq et al. 2002; Schaffert et al. 2004; Staněk and 
Neugebauer 2004; Trinkle-Mulcahy and Sleeman 2017). Some RNP granules appear more specific to particular RNAs. For example, paraspeckles are thought to essentially contain multiple copies of the NEAT1 RNA (Clemson et al. 2009). Similarly, RNP foci observed from repeat expansion RNAs are inferred to be made up solely of those RNAs with repeat expansions (Česnik et al. 2019). However, given the tendency of RNA to interact with other RNA molecules (Van Treeck et al. 2018; Tauber et al. 2020), one anticipates that additional RNAs, perhaps in relatively nonspecific manners, will be localized to these structures.

Second, some RNP granules form locally when a new population of RNA is produced. This is observed for the nucleolus, wherein the production of nascent ribosomal RNA (rRNA) transcripts is required for the formation of the nucleolus (Mélèse and Xue 1995; Falahati et al. 2016). Similarly, the formation of the histone locus body (HLB) occurs when histone mRNAs are produced at high rates (Shevtsov and Dundr 2011). Paraspeckles also require NEAT1 transcription for formation and maintenance (Mao et al. 2011; Naganuma and Hirose 2013). One anticipates that anytime a transcript is produced at high rates, and from repeated genes, it would generate a transient RNP granule as a result of the interactions between RNAs and RBPs.
Third, because the assembly of RNPs into granules may be a relatively promiscuous process, one should expect that even highly specialized RNP granules will contain other RNAs. For example, the formation of P-granules in $C$. elegans is critical for the delivery of a few specific mRNAs to the germline precursor cells, yet P-granules contain a large number of mRNA molecules that are simply carried along for the ride and may contribute to the formation of P-granules by acting as scaffolds for RBPs or through RNA-RNA interactions (Lee et al. 2020). In other words, because RNP granule formation requires a critical concentration to form above the activity of RNA decondensers (Tauber et al. 2020), one way of achieving the critical concentration is to include additional nontranslating RNA and lncRNAs that are not necessary to be transported per se but allow the formation of the granule.

\section{HOW DO RNP GRANULES FORM?}

It is now clear that RNP granules form from a summation of multivalent interactions between individual RNPs (Fig. 2) (Mittag and Parker 2018; Van Treeck and Parker 2018). The multivalent nature of these interactions allows for the formation of large assemblies containing up to hundreds of RNPs, as in the case of stress granules (Khong

\section{Types of protein-protein interactions}
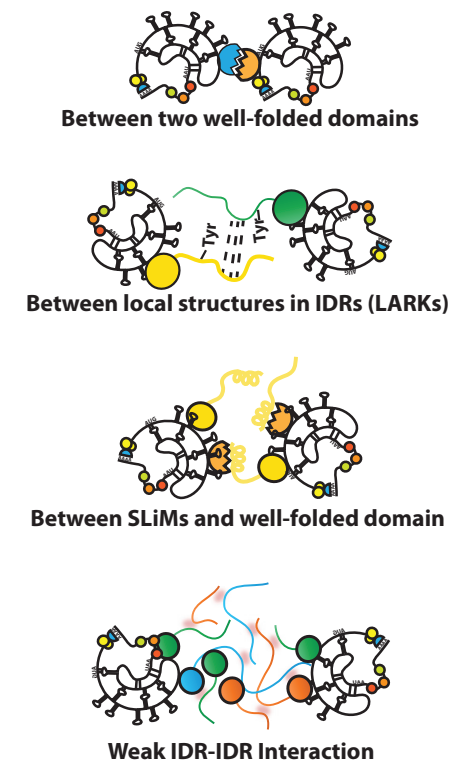

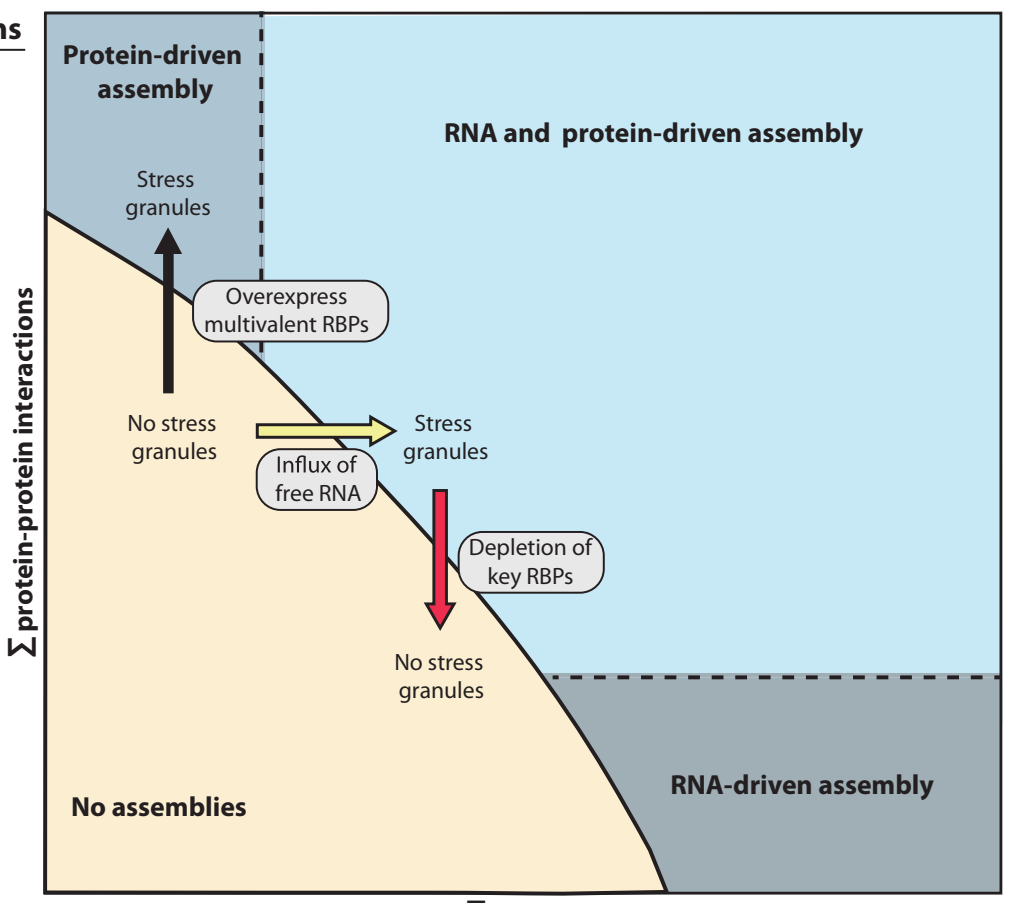

$\sum$ RNA-RNA interactions

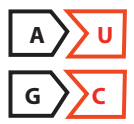

Watson-Crick Base Pairs

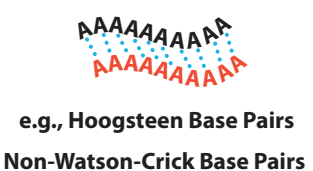

AAAAAAAP
AAAAAAAAAP

Non-Watson-Crick Base Pairs

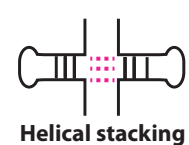

Helical stacking

Figure 2. Summation model for RNP granule formation. Protein-protein interactions such as those between intrinsically disordered regions (IDRs), LARKs, short linear motifs (SLiMs), or well-folded domains contribute to granule formation, as do RNA-RNA interactions such as Watson-Crick base pairs and non-Watson-Crick base pairs, and possibly helical stacking between RNAs. Increasing or decreasing the availability of any one type of interaction can induce or prevent RNP granule formation. 
et al. 2017). RNPs can interact either through proteinprotein, protein-RNA, and/or RNA-RNA interactions.

Protein-protein interactions promoting RNP granule formation occur between RBPs bound to different RNAs and can involve well-folded protein domains (for review, see Mittag and Parker 2018). For example, the dimerization of G3BP1 or EDC3 promotes SG formation in mammals (Tourrière et al. 2003) or PBs in yeast (Ling et al. 2008), respectively. Similarly, depletion of coilin prevents Cajal body formation (Kaiser et al. 2008; Walker et al. 2009; Nizami et al. 2010). However, many RNP granule proteins contain intrinsically disordered regions (IDRs) that can also contribute to RNP granule assembly (Gilks et al. 2004; Decker et al. 2007; Lee et al. 2020). The IDRs of RBPs can promote RNP granule formation in multiple ways, including forming short linear motif (SLiM) interactions with well-folded domains (Jonas and Izaurralde 2013) or by forming local regions of structure that stabilize interactions (Hughes et al. 2018).

Purified RNP granule proteins, or their IDR domains, can also self-assemble in vitro through liquid-liquid phase separation (LLPS), wherein weak multivalent interactions of the IDRs partition those proteins into a concentrated phase in solution (Elbaum-Garfinkle et al. 2015; Lin et al. 2015; Molliex et al. 2015; Nott et al. 2015; Patel et al. 2015; Lee et al. 2020; Martin et al. 2020). This suggested that IDRs also promote the formation of RNP granules, and other macroscale assemblies, through weak, dynamic interactions. Some IDRs weakly interact with many proteins, referred to as "promiscuous" interactions (Protter et al. 2018). Promiscuous IDRs promote LLPS in vitro and RNP granule formation in cells when coupled to proteins undergoing specific interactions by an increase in avidity of the overall complex (Protter et al. 2018). Such promiscuous interactions are not stereospecifically defined, and therefore an individual IDR can interact with different components of the complex to enhance assembly (Protter et al. 2018).

Proteins affecting RNP granule assembly are controlled by multiple posttranslational modifications (reviewed in Protter and Parker 2016). For example, upon arsenite stress, G3BP and UBAP2L, two RBPs that contribute to mammalian SG formation, are arginine-demethylated within their RGG RNA-binding domains, which is likely to increase their RNA binding and thereby promote SG assembly (Tsai et al. 2016; Hofweber and Dormann 2019; Huang et al. 2020). RNP granule formation can also be affected by phosphorylation (Berchtold et al. 2018), acetylation (Gal et al. 2019; Saito et al. 2019), SUMOlyation (Jongjitwimol et al. 2016), and glycosylation (Ohn et al. 2008). Thus, multiple posttranslational modifications of proteins affect the assembly of RNP granules.

In addition to RNA serving as a scaffold for the recruitment of RBPs, intermolecular RNA-RNA interactions also contribute to RNP granule assembly. A role for intermolecular RNA-RNA interactions in RNP granules was suggested by the observations that RNA molecules can self-assemble in vitro (Aumiller et al. 2016). For example, base-pairing allows oligonucleotides of repeat expansion RNAs to self-assemble in vitro, suggesting that intermolecular RNA-RNA interactions contribute to the formation of nuclear RNP foci of repeat expansions RNAs (Jain and Vale 2017). Moreover, when purified cellular RNA is incubated under approximately physiological concentrations and salts, RNA assemblies form whose composition is biased toward longer RNAs and largely matches the stress granule transcriptome (Van Treeck et al. 2018). Because longer RNAs are more prone to self-assembly through RNA-RNA interactions, this observation provides a possible biophysical explanation for why SGs and PBs are generally enriched in longer RNAs (Hubstenberger et al. 2017; Khong et al. 2017; Namkoong et al. 2018; Matheny et al. 2019). However, based on the ability of proteins to target RNAs to RNP granules (see below), one anticipates that, on average, longer RNAs will also have more binding sites for proteins that contribute to RNP recruitment. In the Drosophila embryo, homotypic intermolecular base-pairing between oskar or bicoid mRNAs determines whether those mRNAs localize to RNP granules in the anterior or the posterior of the embryo (Ferrandon et al. 1997; Jambor et al. 2011). This latter observation demonstrates that cells can use specific intermolecular RNA-RNA interactions for RNP granule assembly.

Cells have developed multiple mechanisms to modulate intermolecular RNA-RNA interactions and thereby control the process of RNP granule formation. For mRNAs, this includes elongating ribosomes, which limit the association of mRNAs with SGs and PBs (see below). Similarly, monovalent RNA binding proteins, such as YB-1, can bind to RNA and compete for RNA-RNA interactions that would otherwise promote RNP granule assembly (Bounedjah et al. 2014). The family of DEAD/DEVHbox "RNA helicases," which are ATP-dependent RNAbinding proteins, are found in essentially every RNP granule (Gruidl et al. 1996; Hubstenberger et al. 2013, 2017; Calo et al. 2015; Nott et al. 2015; Jain et al. 2016) and play two roles in modulating RNP granule formation. Monovalent DEAD-box proteins such as eIF4A or DDX19A can limit RNP granule formation by competing for RNA-RNA interactions, including those that occur in trans (Tauber et al. 2020). Conversely, DEAD-box proteins that have additional multimerization domains can promote RNP granule formation, presumably by forming protein-protein interactions that crosslink RNAs together into higher-order structures (Hondele et al. 2019). RNP granule formation is also modulated by the local concentration of RNA. For example, depletion of cytosolic mRNAs by RNase L induction alters stress granule assembly (Burke et al. 2019). Conversely, RNP granules can be nucleated by high local concentration of RNA, such as those produced by rRNA transcription leading to the nucleolus, or translational shutoff increasing the pool of nontranslating RNA in the cytoplasm, which induces SG formation (Falahati et al. 2016; Protter and Parker 2016).

\section{RECRUITMENT OF RNPS TO RNP GRANULES}

A key step in partitioning RNPs into RNP granules is the interaction of RNPs with the surface of an RNP gran- 


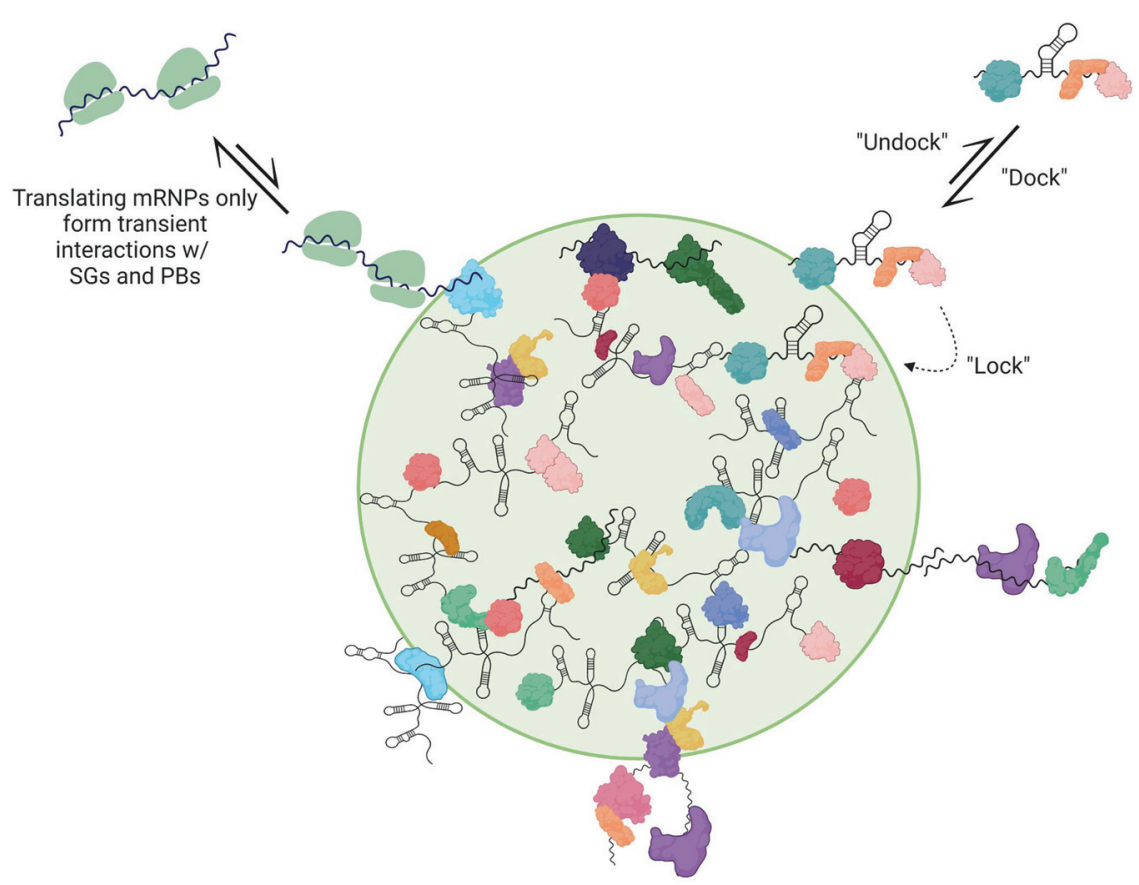

Figure 3. The surface of RNP granules are dynamic and recruit mRNPs. Formation of a transient surface interaction ("docking”) can lead to more stable interactions ("locking"). Translating mRNPs only interact transiently with P-bodies (PBs) and stress granules (SGs), whereas nontranslating mRNPs may form transient or stable interactions.

ule and/or the subsequent stable interaction of the RNP with the RNP granule. Although limited information is available about this process, we consider what is known about mRNP partitioning into stress granules and/or Pbodies to begin to address the mechanisms that modulate RNPs interacting with RNP granules.

The imaging of single mRNAs has revealed that mRNPs interact with SGs and PBs in mammalian cells in two manners (Fig. 3). Both stable and dynamic interactions of RNPs have been observed for PBs (Pitchiaya et al. 2019). For both PBs and SGs, one population of mRNAs is relatively stable in these RNP granules and can be rigidly positioned within the granule (Moon et al. 2019). A second population of RNPs transiently interacts with the surface of these granules, showing rapid exchange with the bulk cytosol with an average dwell time on the granule surface of $\sim 10 \mathrm{sec}$ (Moon et al. 2019). Stable associations are increased with granule size and mRNA length and decreased by ribosome association with the mRNA (Moon et al. 2019). These observations suggested a "dock and lock" model wherein RNPs can form transient protein or RNA-based interactions with the surface of an RNP granule, and that surface association can lead to formation of more interactions, leading to a stable association of the RNP with the granule (Moon et al. 2019). Interestingly, surface binding leading to more stable associations through the creation of a high local concentration can also occur on the surface of RNA condensates created from an RNA homopolymer (Tauber et al. 2020), suggesting that surface interactions of RNP granules will be critical in controlling the entry and egress of RNPs.

\section{FACTORS AFFECT RNPS PARTITIONING INTO STRESS GRANULES AND P-BODIES}

Examination of the composition of both SGs and PBs has revealed that there can be substantial differences in the partitioning of individual mRNAs into these assemblies. On a correlative level, both assemblies are biased toward longer, poorly translated mRNAs (Hubstenberger et al. 2017; Khong et al. 2017; Namkoong et al. 2018; Matheny et al. 2019). Similar results are seen for the collection of mRNAs enriched in C. elegans P-granules (Lee et al. 2020). In addition to these correlations, further experiments have revealed both positive and negative components of RNPs that affects their assembly into these complexes.

Three observations argue that the engagement of an $80 \mathrm{~S}$ ribosome limits the ability of an mRNP to stably associate with a SG or PB. First, trapping mRNAs in polysomes with translation elongation inhibitors prevents SG, PB, and P-granule formation (Kedersha et al. 2000; Brengues et al. 2005; Lee et al. 2020), demonstrating that these assemblies require mRNAs dissociated from ribosomes for their stable formation. Second, mRNAs with long coding regions are delayed in their accumulation in stress granules after translation inhibition in a ribosome-dependent manner (Khong and Parker 2018). Finally, simultaneous monitoring of translation status and interaction with the RNP granules of single mRNPs revealed that mRNAs engaged with ribosomes can only interact with SGs or PBs in the dynamic mode and are unable to enter the stable state (Moon et al. 2019). Thus, mRNAs engaged with ribosomes can interact with SGs 
and PBs but are unable to form a stable interaction. This suggests that the energetic cost of partitioning a ribosome into an RNP granule is significant, perhaps because of continued ribosome elongation, an absence of stabilizing interactions between the ribosome and other RNP granule components, or an altered geometry to the mRNA owing to elongating ribosomes (Adivarahan et al. 2018; Khong and Parker 2018).

Individual RNPs can be targeted to RNP granules by the combined action of multiple positive elements. For example, insertion of the NORAD lncRNA, which is highly enriched in SGs (Khong et al. 2017), into a reporter efficiently targets that reporter RNA into SGs (Matheny et al. 2020). Moreover, deletion analysis of NORAD demonstrates that multiple regions of NORAD act in an additive manner to promote SG accumulation of the RNA (Matheny et al. 2020). The number of binding sites for known SG RBPs within the region of NORAD inserted into the reporter correlates with increased SG enrichment, whereas control RNAs of the same length, but without known sites for RBPs, showed lesser accumulation in SGs (Matheny et al. 2020). This suggests that the SG accumulation of NORAD may be largely dictated by the presence of multiple binding sites for SG proteins and raises the possibility that nonspecific RNA-RNA interactions contribute less to the SG accumulation of NORAD RNA.

More direct evidence that some RNA-binding proteins can target RNPs into SGs has come from examining how artificial tethering of proteins to reporter RNAs affects their accumulation in SGs. For example, the tethering of G3BP1 or TIA-1 to a luciferase reporter mRNA increases its accumulation in stress granules in a dose-dependent manner (Matheny et al. 2020). This provides direct evidence that proteins bound to an RNA can dictate its accumulation in an RNP granule. This is consistent with the observations that in $C$. elegans, the $\mathrm{P}$ granule protein MEG-3 is required for proper mRNA localization and P-granule formation in germ cells (Lee et al. 2020), and that in neurons, trafficking of specific mRNAs in neuronal transport granules is dependent on sequence motifs for the binding of heterogeneous nuclear ribonucleoprotein (hnRNP) A2 and A3 (Shan et al. 2000). Similarly, sequence elements in the 3' UTR of Drosophila germ granule RNAs are necessary and sufficient for localization in maternal mRNA granules (Rangan et al. 2009).

The observation that NORAD contains many elements promoting SG accumulation and the observation that efficient SG targeting by tethered proteins requires 25 sites of tethering suggest a model wherein the accumulation of a given RNP into a SG is due to the summation of many interactions (Matheny et al. 2020). This view is consistent with the strong bias toward longer RNAs in SGs, which by their length would simply have more sites for positive interactions. Interestingly, this summative model predicts that any given protein would have small effects on the set of RNAs that accumulate in a SG. This provides an explanation for the surprising observation that U-2 OS cells lacking G3BP1 and G3BP2, two abundant and important proteins for SG formation, form SGs with essentially the same transcriptome as wild-type cells (Matheny et al. 2020).

\section{HOW DO CELLS SORT RNPS BETWEEN MULTIPLE GRANULES?}

The combination of translation status and sets of specific interactions allows cells to form multiple types of RNP granules with distinct RNA and protein compositions in the same compartment. For example, P-bodies in unstressed cells are biased toward poorly translated mRNAs and have a distinctly different mRNA composition than stress granules (Fig. 4). (Hubstenberger et al. 2017; Matheny et al. 2019). However, during stress conditions, when most mRNAs cease translation, the transcriptome of P-bodies and stress granules is very similar (Matheny et al. 2019). During such stress conditions, individual mRNPs then can be understood as partitioning into stress granules or P-bodies based on their RNA binding proteins. Because proteins found in P-bodies or stress granules preferentially interact with themselves (Jonas and Izaurralde 2013; Youn et al. 2018), this would allow two distinct forms of mRNPs that partition into stress granules or P-bodies, respectively. Such distinct mRNPs could be dictated by the status of the poly(A) tail because deadenylated mRNAs are preferentially bound by specific components of P-bodies (Bouveret et al. 2000; Tharun et al. 2000), which would then target deadenylated molecules to P-bodies, consistent with P-bodies failing to stain for poly(A) ${ }^{+}$mRNA by oligo(dT) FISH, whereas SGs do (Kedersha et al. 2000; Cougot et al. 2004). Similarly, specific RNA-RNA interactions can target the bicoid or oskar RNAs to anterior or posterior RNP granules during Drosophila oogenesis (Ferrandon et al. 1997; Jambor et al. 2011).

Partitioning of RNPs into different RNP granules may also be controlled by RNA structures that form to limit any RNA-RNA interactions between components. For example, it is suggested in the filamentous fungi, Ashbya gossypii, that the tertiary structure of the CLN3 mRNA, which associates with the Whi3 protein and forms RNP granules, limits the CLN3 mRNA's possible interactions with other mRNAs that also interact with Whi3, thereby giving rise to distinct RNP granules (Langdon et al. 2018).

\section{CONCLUSION}

The combination of available protein and RNA-based interactions determines whether an RNP granule will form and whether an individual RNP will partition into the granule. The diversity of interactions allows for redundancy in RNP granule formation as well as many layers of potential regulation. Future work to understand how the availability of these interactions is regulated will be important for understanding how aberrant granules form in neurological disease. 
Nonstressed conditions

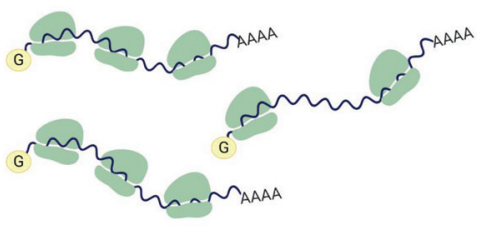

Majority of mRNAs engaged in translation

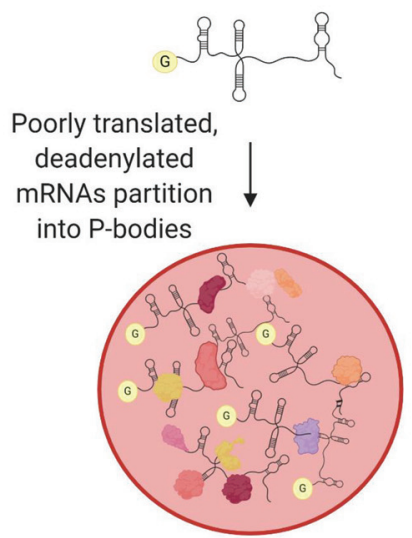

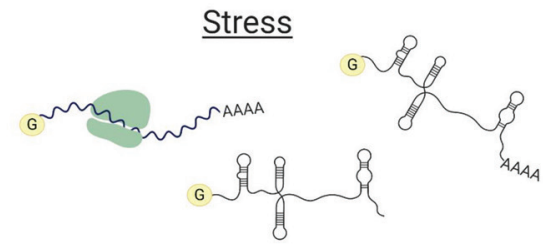

Translational shutoff-most mRNAs released from ribosomes
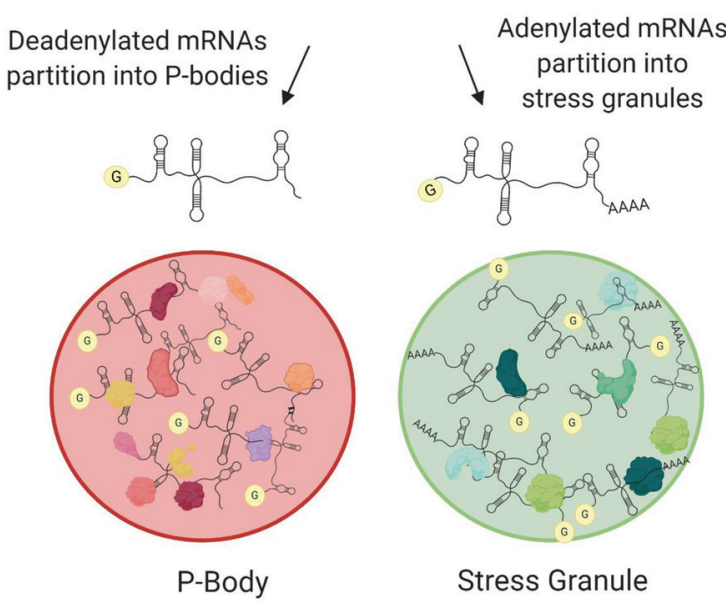

Figure 4. P-bodies and stress granules are composed of nontranslating mRNPs. During nonstressed conditions (left), only P-bodies are present, and nontranslating, deadenylated mRNAs partition into P-bodies. During stress (right), both P-bodies and stress granules are present in cytosol, and mRNAs may partition into either stress granules or P-bodies, likely dictated by their poly(A) status.

\section{REFERENCES}

Adivarahan S, Livingston N, Nicholson B, Rahman S, Wu B, Rissland OS, Zenklusen D. 2018. Spatial organization of single mRNPs at different stages of the gene expression pathway. Mol Cell 72: 727-738.e5. doi:10.1016/j.molcel.2018.10.010

Al-Husini N, Tomares DT, Bitar O, Childers WS, Schrader JM. 2018. $\alpha$-Proteobacterial RNA degradosomes assemble liquidliquid phase-separated RNP bodies. Mol Cell 71: 1027-1039. e14. doi:10.1016/j.molcel.2018.08.003

Almeida S, Gascon E, Tran H, Chou HJ, Gendron TF, DeGroot S, Tapper AR, Sellier C, Charlet-Berguerand N, Karydas A, et al. 2013. Modeling key pathological features of frontotemporal dementia with C9ORF72 repeat expansion in iPSC-derived human neurons. Acta Neuropathol (Berl) 126: 385-399. doi:10.1007/s00401-013-1149-y

Arai T, Hasegawa M, Akiyama H, Ikeda K, Nonaka T, Mori H, Mann D, Tsuchiya K, Yoshida M, Hashizume Y, et al. 2006. TDP-43 is a component of ubiquitin-positive tau-negative inclusions in frontotemporal lobar degeneration and amyotrophic lateral sclerosis. Biochem Biophys Res Commun 351: 602-611. doi:10.1016/j.bbrc.2006.10.093

Arkov AL, Wang J-YS, Ramos A, Lehmann R. 2006. The role of Tudor domains in germline development and polar granule architecture. Development 133: 4053-4062. doi:10.1242/dev .02572

Aumiller WM, Pir Cakmak F, Davis BW, Keating CD. 2016. RNA-based coacervates as a model for membraneless organelles: formation, properties, and interfacial liposome assembly. Langmuir 32: 10042-10053. doi:10.1021/acs.langmuir .6b02499

Berchtold D, Battich N, Pelkmans L. 2018. A systems-level study reveals regulators of membrane-less organelles in human cells. Mol Cell 72: 1035-1049.e5. doi:10.1016/j.molcel.2018.10 .036
Bergovich K, Vu AQ, Yeo GW, Wilhelm JE. 2020. Conserved metabolite regulation of stress granule assembly via AdoMet. J Cell Biol doi:10.1083/jcb.2019.04141

Boisvert F-M, van Koningsbruggen S, Navascués J, Lamond AI. 2007. The multifunctional nucleolus. Nat Rev Mol Cell Biol 8: 574-585. doi:10.1038/nrm2184

Bond CS, Fox AH. 2009. Paraspeckles: nuclear bodies built on long noncoding RNA. J Cell Biol 186: 637-644. doi:10.1083/ jcb.200906113

Bounedjah O, Desforges B, Wu T-D, Pioche-Durieu C, Marco S, Hamon L, Curmi PA, Guerquin-Kern J-L, Piétrement O, Pastré D. 2014. Free mRNA in excess upon polysome dissociation is a scaffold for protein multimerization to form stress granules. Nucleic Acids Res 42: 8678-8691. doi:10.1093/nar/gku582

Bouveret E, Rigaut G, Shevchenko A, Wilm M, Séraphin B. 2000. A Sm-like protein complex that participates in mRNA degradation. EMBO J 19: 1661-1671. doi:10.1093/emboj/19 .7 .1661

Brengues M, Teixeira D, Parker R. 2005. Movement of eukaryotic mRNAs between polysomes and cytoplasmic processing bodies. Science 310: 486-489. doi:10.1126/science.1115791

Buchan JR, Parker R. 2009. Eukaryotic stress granules: the ins and outs of translation. Mol Cell 36: 932-941. doi:10.1016/j .molcel.2009.11.020

Buchan JR, Muhlrad D, Parker R. 2008. P bodies promote stress granule assembly in Saccharomyces cerevisiae. J Cell Biol 183: 441-455. doi: $10.1083 /$ jcb.200807043

Buchan JR, Kolaitis R-M, Taylor JP, Parker R. 2013. Eukaryotic stress granules are cleared by granulophagy and Cdc48/VCP function. Cell 153: 1461-1474. doi:10.1016/j.cell.2013.05 .037

Burke JM, Moon SL, Matheny T, Parker R. 2019. RNase L reprograms translation by widespread mRNA turnover escaped by antiviral mRNAs. Mol Cell 75: 1203-1217.e5. doi:10 $.1016 /$ j.molcel.2019.07.029 
Calo E, Flynn RA, Martin L, Spitale RC, Chang HY, Wysocka J. 2015. RNA helicase DDX21 coordinates transcription and ribosomal RNA processing. Nature 518: 249-253. doi:10 $.1038 /$ nature 13923

Carmo-Fonseca M. 2002. New clues to the function of the Cajal body. EMBO Rep 3: 726-727. doi:10.1093/embo-reports/ kvf154

Česnik AB, Darovic S, Miheve SP, Štalekar M, Malnar M, Motaln H, Lee Y-B, Mazej J, Pohleven J, Grosch M, et al. 2019. Nuclear RNA foci from C9ORF72 expansion mutation form paraspeckle-like bodies. J Cell Sci 132: jcs224303. doi: $10.1242 /$ jes. 224303

Chamberland H, Lafontaine JG. 1993. Localization of snRNP antigens in nucleolus-associated bodies: study of plant interphase nuclei by confocal and electron microscopy. Chromosoma 102: 220-226. doi:10.1007/BF00352395

Cioce M, Lamond AI. 2005. Cajal bodies: a long history of discovery. Annu Rev Cell Dev Biol 21: 105-131. doi:10 .1146/annurev.cellbio.20.010403.103738

Cirillo L, Cieren A, Barbieri S, Khong A, Schwager F, Parker R, Gotta M. 2020. UBAP2L forms distinct cores that act in nucleating stress granules upstream of G3BP1. Curr Biol 30: 698-707.e6. doi:10.1016/j.cub.2019.12.020

Clemson CM, Hutchinson JN, Sara SA, Ensminger AW, Fox AH, Chess A, Lawrence JB. 2009. An architectural role for a nuclear noncoding RNA: NEAT1 RNA is essential for the structure of paraspeckles. Mol Cell 33: 717-726. doi:10.1016/j .molcel.2009.01.026

Cougot N, Babajko S, Séraphin B. 2004. Cytoplasmic foci are sites of mRNA decay in human cells. J Cell Biol 165: 31-40. doi: $10.1083 /$ jcb. 200309008

Courel M, Clément Y, Bossevain C, Foretek D, Vidal Cruchez O, Yi Z, Bénard M, Benassy M-N, Kress M, Vindry C, et al. 2019. GC content shapes mRNA storage and decay in human cells. ELife 8: e49708. doi:10.7554/eLife.49708

Darzacq X, Jády BE, Verheggen C, Kiss AM, Bertrand E, Kiss T. 2002. Cajal body-specific small nuclear RNAs: a novel class of 2'-O-methylation and pseudouridylation guide RNAs. EMBO J 21: 2746-2756. doi:10.1093/emboj/21.11.2746

Davis BM, McCurrach ME, Taneja KL, Singer RH, Housman DE. 1997. Expansion of a CUG trinucleotide repeat in the $3^{\prime}$ untranslated region of myotonic dystrophy protein kinase transcripts results in nuclear retention of transcripts. Proc Natl Acad Sci 94: 7388-7393. doi:10.1073/pnas.94.14.7388

Decker CJ, Teixeira D, Parker R. 2007. Edc3p and a glutamine/ asparagine-rich domain of Lsm $4 p$ function in processing body assembly in Saccharomyces cerevisiae. J Cell Biol 179: 437449. doi:10.1083/jcb.200704147

DeJesus-Hernandez M, Mackenzie IR, Boeve BF, Boxer AL, Baker M, Rutherford NJ, Nicholson AM, Finch NA, Flynn H, Adamson J, et al. 2011. Expanded GGGGCC hexanucleotide repeat in noncoding region of C9ORF72 causes chromosome 9p-Linked FTD and ALS. Neuron 72: 245-256. doi:10 .1016/j.neuron.2011.09.011

Desterro JMP, Keegan LP, Lafarga M, Berciano MT, O’Connell M, Carmo-Fonseca M. 2003. Dynamic association of RNAediting enzymes with the nucleolus. J Cell Sci 116: 18051818. doi:10.1242/jcs.00371

Dickson DW, Kouri N, Murray ME, Josephs KA. 2011. Neuropathology of frontotemporal lobar degeneration-tau (FTLDTau). J Mol Neurosci 45: 384-389. doi:10.1007/s12031-0119589-0

Dundr M, Olson MOJ. 1998. Partially processed pre-rRNA is preserved in association with processing components in nucleolus-derived foci during mitosis. Mol Biol Cell 9: 2407-2422. doi: $10.1091 / \mathrm{mbc}$.9.9.2407

Elbaum-Garfinkle S, Kim Y, Szczepaniak K, Chen CC-H, Eckmann CR, Myong S, Brangwynne CP. 2015. The disordered P granule protein LAF-1 drives phase separation into droplets with tunable viscosity and dynamics. Proc Natl Acad Sci 112: 7189-7194. doi:10.1073/pnas.1504822112

Ephrussi A, Lehmann R. 1992. Induction of germ cell formation by oskar. Nature 358: 387-392. doi:10.1038/358387a0
Eulalio A, Behm-Ansmant I, Schweizer D, Izaurralde E. 2007. Pbody formation is a consequence, not the cause, of RNA-mediated gene silencing. Mol Cell Biol 27: 3970-3981. doi:10 .1128/MCB.00128-07

Falahati H, Pelham-Webb B, Blythe S, Wieschaus E. 2016. Nucleation by rRNA dictates the precision of nucleolus assembly. Curr Biol 26: 277-285. doi:10.1016/j.cub.2015.11.065

Fatica A, Tollervey D. 2002. Making ribosomes. Curr Opin Cell Biol 14: 313-318. doi:10.1016/S0955-0674(02)00336-8

Ferrandon D, Koch I, Westhof E, Nüsslein-Volhard C. 1997. RNA-RNA interaction is required for the formation of specific bicoid mRNA 3' UTR-STAUFEN ribonucleoprotein particles. EMBO J 16: 1751-1758. doi:10.1093/emboj/16.7.1751

Fox AH, Lamond AI. 2010. Paraspeckles. Cold Spring Harb Perspect Biol 2: a000687. doi:10.1101/cshperspect.a000687

Fox AH, Nakagawa S, Hirose T, Bond CS. 2018. Paraspeckles: where long noncoding RNA meets phase separation. Trends Biochem Sci 43: 124-135. doi:10.1016/j.tibs.2017.12.001

Fratta P, Mizielinska S, Nicoll AJ, Zloh M, Fisher EMC, Parkinson G, Isaacs AM. 2012. C9orf72 hexanucleotide repeat associated with amyotrophic lateral sclerosis and frontotemporal dementia forms RNA G-quadruplexes. Sci Rep 2: 1016. doi:10 $.1038 /$ srep01016

Frottin F, Schueder F, Tiwary S, Gupta R, Körner R, Schlichthaerle T, Cox J, Jungmann R, Hartl FU, Hipp MS. 2019. The nucleolus functions as a phase-separated protein quality control compartment. Science 365: 342-347. doi:10.1126/science .aaw9157

Gal J, Chen J, Na D-Y, Tichacek L, Barnett KR, Zhu H. 2019. The acetylation of lysine-376 of G3BP1 regulates RNA binding and stress granule dynamics. Mol Cell Biol 39: e00052-19. doi:10.1128/MCB.00052-19

Gall JG, Bellini M, Wu Z, Murphy C. 1999. Assembly of the nuclear transcription and processing machinery: Cajal bodies (coiled bodies) and transcriptosomes. Mol Biol Cell 10: 43854402. doi:10.1091/mbc.10.12.4385

Gendron TF, Bieniek KF, Zhang Y-J, Jansen-West K, Ash PEA, Caulfield T, Daughrity L, Dunmore JH, Castanedes-Casey M, Chew J, et al. 2013. Antisense transcripts of the expanded C9ORF72 hexanucleotide repeat form nuclear RNA foci and undergo repeat-associated non-ATG translation in c9FTD/ ALS. Acta Neuropathol (Berl) 126: 829-844. doi:10.1007/ s00401-013-1192-8

Gilks N, Kedersha N, Ayodele M, Shen L, Stoecklin G, Dember LM, Anderson P. 2004. Stress granule assembly is mediated by prion-like aggregation of TIA-1. Mol Biol Cell 15: 53835398. doi:10.1091/mbc.e04-08-0715

Gruidl ME, Smith PA, Kuznicki KA, McCrone JS, Kirchner J, Roussell DL, Strome S, Bennett KL. 1996. Multiple potential germ-line helicases are components of the germ-line-specific P granules of Caenorhabditis elegans. Proc Natl Acad Sci 93: 13837-13842. doi:10.1073/pnas.93.24.13837

Hay B, Jan LY, Jan YN. 1988. A protein component of Drosophila polar granules is encoded by vasa and has extensive sequence similarity to ATP-dependent helicases. Cell 55: 577-587. doi:10.1016/0092-8674(88)90216-4

Hebert MD, Matera AG. 2000. Self-association of coilin reveals a common theme in nuclear body localization. Mol Biol Cell 11: 4159-4171. doi:10.1091/mbc.11.12.4159

Hebert MD, Poole AR. 2016. Towards an understanding of regulating Cajal body activity by protein modification. RNA Biol 14: 761-778. doi:10.1080/15476286.2016.1243649

Hofmann S, Cherkasova V, Bankhead P, Bukau B, Stoecklin G. 2012. Translation suppression promotes stress granule formation and cell survival in response to cold shock. Mol Biol Cell 23: 3786-3800. doi:10.1091/mbc.e12-04-0296

Hofweber M, Dormann D. 2019. Friend or foe-post-translational modifications as regulators of phase separation and RNP granule dynamics. J Biol Chem 294: 7137-7150. doi:10 $.1074 /$ jbc.TM118.001189

Hondele M, Sachdev R, Heinrich S, Wang J, Vallotton P, Fontoura BMA, Weis K. 2019. DEAD-box ATPases are global 
regulators of phase-separated organelles. Nature 573: 144 148. doi:10.1038/s41586-019-1502-y

Hsieh Y-C, Guo C, Yalamanchili HK, Abreha M, Al-Ouran R, Li Y, Dammer EB, Lah JJ, Levey AI, Bennett DA, et al. 2019. Tau-mediated disruption of the spliceosome triggers cryptic RNA splicing and neurodegeneration in Alzheimer's disease. Cell Rep 29: 301-316.e10. doi:10.1016/j.celrep.2019.08.104

Huang C, Chen Y, Dai H, Zhang H, Xie M, Zhang H, Chen F, Kang X, Bai X, Chen Z. 2020. UBAP2L arginine methylation by PRMT1 modulates stress granule assembly. Cell Death Differ 27: 227-241. doi:10.1038/s41418-019-0350-5

Hubstenberger A, Noble SL, Cameron C, Evans TC. 2013. Translation repressors, an RNA helicase, and developmental cues control RNP phase transitions during early development. Dev Cell 27: 161-173. doi:10.1016/j.devcel.2013.09.024

Hubstenberger A, Courel M, Bénard M, Souquere S, ErnoultLange M, Chouaib R, Yi Z, Morlot J-B, Munier A, Fradet M, et al. 2017. P-body purification reveals the condensation of repressed mRNA regulons. Mol Cell 68: 144-157.e5. doi:10 .1016/j.molcel.2017.09.003

Hughes M, Sawaya MR, Boyer DR, Goldschmidt L, Rodriguez JA, Cascio D, Chong L, Gonen T, Eisenberg DS. 2018. Atomic structures of low-complexity protein segments reveal kinked $\beta$ sheets that assemble networks. Science 359: 698-701. doi:10 $.1126 /$ science.aan6398

Imamura K, Imamachi N, Akizuki G, Kumakura M, Kawaguchi A, Nagata K, Kato A, Kawaguchi Y, Sato H, Yoneda M, et al. 2014. Long noncoding RNA NEAT1-dependent SFPQ relocation from promoter region to paraspeckle mediates IL8 expression upon immune stimuli. Mol Cell 53: 393-406. doi:10 .1016/j.molcel.2014.01.009

Jain A, Vale RD. 2017. RNA phase transitions in repeat expansion disorders. Nature 546: 243-247. doi:10.1038/ nature22386

Jain S, Wheeler JR, Walters RW, Agrawal A, Barsic A, Parker R. 2016. ATPase-modulated stress granules contain a diverse proteome and substructure. Cell 164: 487-498. doi:10.1016/j.cell .2015 .12 .038

Jambor H, Brunel C, Ephrussi A. 2011. Dimerization of oskar 3' UTRs promotes hitchhiking for RNA localization in the Drosophila oocyte. RNA 17: 2049-2057. doi:10.1261/rna .2686411

Jiang H, Mankodi A, Swanson MS, Moxley RT, Thornton CA. 2004. Myotonic dystrophy type 1 is associated with nuclear foci of mutant RNA, sequestration of muscleblind proteins and deregulated alternative splicing in neurons. Hum Mol Genet 13: $3079-3088$. doi: $10.1093 / \mathrm{hmg} / \mathrm{ddh} 327$

Jonas S, Izaurralde E. 2013. The role of disordered protein regions in the assembly of decapping complexes and RNP granules. Genes Dev 27: 2628-2641. doi:10.1101/gad.227843.113

Jones JR, Macdonald PM. 2007. Oskar controls morphology of polar granules and nuclear bodies in Drosophila. Development 134: 233-236. doi:10.1242/dev.02729

Jongjitwimol J, Baldock RA, Morley SJ, Watts FZ. 2016. Sumoylation of eIF4A2 affects stress granule formation. $J$ Cell Sci 129: 2407-2415. doi:10.1242/jcs. 184614

Kaiser TE, Intine RV, Dundr M. 2008. De novo formation of a subnuclear body. Science 322: 1713-1717. doi:10.1126/sci ence. 1165216

Kedersha NL, Gupta M, Li W, Miller I, Anderson P. 1999. RNAbinding proteins Tia-1 and Tiar link the phosphorylation of Eif- $2 \alpha$ to the assembly of mammalian stress granules. $J$ Cell Biol 147: 1431-1442. doi:10.1083/jcb.147.7.1431

Kedersha N, Cho MR, Li W, Yacono PW, Chen S, Gilks N, Golan DE, Anderson P. 2000. Dynamic shuttling of Tia-1 accompanies the recruitment of mRNA to mammalian stress granules. $J$ Cell Biol 151: 1257-1268. doi:10.1083/jcb.151.6.1257

Kedersha N, Stoecklin G, Ayodele M, Yacono P, Lykke-Andersen J, Fritzler MJ, Scheuner D, Kaufman RJ, Golan DE, Anderson P. 2005. Stress granules and processing bodies are dynamically linked sites of mRNP remodeling. J Cell Biol 169: $871-884$. doi: $10.1083 /$ jcb. 200502088
Kedersha N, Ivanov P, Anderson P. 2013. Stress granules and cell signaling: more than just a passing phase? Trends Biochem Sci 38: 494-506. doi:10.1016/j.tibs.2013.07.004

Kedersha N, Panas MD, Achorn CA, Lyons S, Tisdale S, Hickman T, Thomas M, Lieberman J, McInerney GM, Ivanov P, et al. 2016. G3BP-Caprin1-USP10 complexes mediate stress granule condensation and associate with $40 \mathrm{~S}$ subunits. $J$ Cell Biol 212: 845-860. doi:10.1083/jcb.201508028

Khong A, Parker R. 2018. mRNP architecture in translating and stress conditions reveals an ordered pathway of mRNP compaction. J Cell Biol 217: 4124-4140. doi: $10.1083 / \mathrm{jcb}$ .201806183

Khong A, Matheny T, Jain S, Mitchell SF, Wheeler JR, Parker R. 2017. The stress granule transcriptome reveals principles of mRNA accumulation in stress granules. Mol Cell 68: 808-820. e5. doi:10.1016/j.molcel.2017.10.015

Kiebler MA, Bassell GJ. 2006. Neuronal RNA granules: movers and makers. Neuron 51: 685-690. doi:10.1016/j.neuron.2006 .08 .021

Kumar V, Hasan GM, Hassan M. 2017. Unraveling the role of RNA mediated toxicity of C9orf72 repeats in C9-FTD/ALS. Front Neurosci 11: 711. doi:10.3389/fnins.2017.00711

Langdon EM, Qiu Y, Niaki AG, McLaughlin GA, Weidmann CA, Gerbich TM, Smith JA, Crutchley JM, Termini CM, Weeks KM, et al. 2018. mRNA structure determines specificity of a polyQ-driven phase separation. Science 360: 922-927. doi:10.1126/science.aar7432

Lee C-YS, Putnam A, Lu T, He S, Ouyang JPT, Seydoux G. 2020. Recruitment of mRNAs to $P$ granules by condensation with intrinsically-disordered proteins. Elife 9: e52896. doi:10 .7554/eLife.52896

Lin Y, Protter DSW, Rosen MK, Parker R. 2015. Formation and maturation of phase-separated liquid droplets by RNA-binding proteins. Mol Cell 60: 208-219. doi:10.1016/j.molcel.2015.08 .018

Ling SHM, Decker CJ, Walsh MA, She M, Parker R, Song H. 2008. Crystal structure of human Edc3 and its functional implications. Mol Cell Biol 28: 5965-5976. doi:10.1128/MCB 00761-08

Little SC, Sinsimer KS, Lee JJ, Wieschaus EF, Gavis ER. 2015. Independent and coordinate trafficking of single Drosophila germ plasm mRNAs. Nat Cell Biol 17: 558-568. doi:10.1038/ ncb3143

Love AJ, Yu C, Petukhova NV, Kalinina NO, Chen J, Taliansky ME. 2016. Cajal bodies and their role in plant stress and disease responses. RNA Biol 14: 779-790. doi:10.1080/ 15476286.2016.1243650

Maden BEH, Hughes JMX. 1997. Eukaryotic ribosomal RNA: the recent excitement in the nucleotide modification problem. Chromosoma 105: 391-400. doi:10.1007/BF02510475

Mahowald AP. 1971. Polar granules of Drosophila. III. The continuity of polar granules during the life cycle of Drosophila. $J$ Exp Zool 176: 329-343. doi:10.1002/jez.1401760308

Mao YS, Sunwoo H, Zhang B, Spector DL. 2011. Direct visualization of the co-transcriptional assembly of a nuclear body by noncoding RNAs. Nat Cell Biol 13: 95-101. doi:10.1038/ ncb2140

Markmiller S, Soltanieh S, Server KL, Mak R, Jin W, Fang MY, Luo E-C, Krach F, Yang D, Sen A, et al. 2018. Context-dependent and disease-specific diversity in protein interactions within stress granules. Cell 172: 590-604.e13. doi:10.1016/j .cell.2017.12.032

Martin EW, Holehouse AS, Peran I, Farag M, Incicco JJ, Bremer A, Grace CR, Soranno A, Pappu RV, Mittag T. 2020. Valence and patterning of aromatic residues determine the phase behavior of prion-like domains. Science 367: 694-699. doi:10.1126/ science.aaw 8653

Matheny T, Rao BS, Parker R. 2019. Transcriptome-wide comparison of stress granules and P-bodies reveals that translation plays a major role in RNA partitioning. Mol Cell Biol 39: e00313-19. doi:10.1128/MCB.00313-19

Matheny T, Van Treeck B, Huynh TN, Parker R. 2020. RNA partitioning into stress granules is based on the summa- 
tion of multiple interactions. BioRxiv doi:10.1101/2020.04.15 .043646

Mélèse T, Xue Z. 1995. The nucleolus: an organelle formed by the act of building a ribosome. Curr Opin Cell Biol 7: 319324. doi:10.1016/0955-0674(95)80085-9

Mittag T, Parker R. 2018. Multiple modes of protein-protein interactions promote RNP granule assembly. J Mol Biol 430: 4636-4649. doi:10.1016/j.jmb.2018.08.005

Molliex A, Temirov J, Lee J, Coughlin M, Kanagaraj AP, Kim HJ, Mittag T, Taylor JP. 2015. Phase separation by low complexity domains promotes stress granule assembly and drives pathological fibrillization. Cell 163: 123-133. doi:10.1016/j.cell .2015 .09 .015

Moon SL, Morisaki T, Khong A, Lyon K, Parker R, Stasevich TJ. 2019. Multicolor single-molecule tracking of mRNA interactions with RNP granules. Nat Cell Biol 21: 162-168. doi:10 .1038/s41556-018-0263-4

Moon SL, Morisaki T, Stasevich TJ, Parker R. 2020. Coupling of translation quality control and mRNA targeting to stress granules. BioRxiv doi:10.1101/2020.01.05.895342

Mori K, Lammich S, Mackenzie IRA, Forné I, Zilow S, Kretzschmar H, Edbauer D, Janssens J, Kleinberger G, Cruts M, et al. 2013. hnRNP A3 binds to GGGGCC repeats and is a constituent of p62-positive/TDP43-negative inclusions in the hippocampus of patients with C9orf72 mutations. Acta Neuropathol (Berl) 125: 413-423. doi:10.1007/s00401-013-1088-7

Morris GE. 2008. The Cajal body. Biochim Biophys Acta 1783: 2108-2115. doi:10.1016/j.bbamcr.2008.07.016

Naganuma T, Hirose T. 2013. Paraspeckle formation during the biogenesis of long non-coding RNAs. RNA Biol 10: 456-461. doi:10.4161/rna.23547

Naganuma T, Nakagawa S, Tanigawa A, Sasaki YF, Goshima N, Hirose T. 2012. Alternative 3'-end processing of long noncoding RNA initiates construction of nuclear paraspeckles. $E M B O$ $J$ 31: 4020-4034. doi:10.1038/emboj.2012.251

Nakagawa S, Naganuma T, Shioi G, Hirose T. 2011. Paraspeckles are subpopulation-specific nuclear bodies that are not essential in mice. J Cell Biol 193: 31-39. doi:10.1083/jcb.201011110

Nakamura A, Amikura R, Mukai M, Kobayashi S, Lasko PF. 1996. Requirement for a noncoding RNA in Drosophila polar granules for germ cell establishment. Science 274: 20752079. doi:10.1126/science.274.5295.2075

Namkoong S, Ho A, Woo YM, Kwak H, Lee JH. 2018. Systematic characterization of stress-induced RNA granulation. Mol Cell 70: 175-187.e8. doi:10.1016/j.molcel.2018.02.025

Narayanan A, Speckmann W, Terns R, Terns MP. 1999. Role of the box C/D motif in localization of small nucleolar RNAs to coiled bodies and nucleoli. Mol Biol Cell 10: 2131-2147. doi:10.1091/mbc.10.7.2131

Neumann M, Sampathu DM, Kwong LK, Truax AC, Micsenyi MC, Chou TT, Bruce J, Schuck T, Grossman M, Clark CM, et al. 2006. Ubiquitinated TDP-43 in frontotemporal lobar degeneration and amyotrophic lateral sclerosis. Science 314: 130-133. doi:10.1126/science. 1134108

Nizami Z, Deryusheva S, Gall JG. 2010. The Cajal body and histone locus body. Cold Spring Harb Perspect Biol 2: a000653. doi: $10.1101 /$ cshperspect.a000653

Nott TJ, Petsalaki E, Farber P, Jervis D, Fussner E, Plochowietz A, Craggs TD, Bazett-Jones DP, Pawson T, Forman-Kay JD, et al. 2015. Phase transition of a disordered nuage protein generates environmentally responsive membraneless organelles. Mol Cell 57: 936-947. doi:10.1016/j.molcel.2015.01 .013

Ohn T, Kedersha N, Hickman T, Tisdale S, Anderson P. 2008. A functional RNAi screen links $O$-GlcNAc modification of ribosomal proteins to stress granule and processing body assembly. Nat Cell Biol 10: 1224-1231. doi:10.1038/ncb1783

Olson MOJ, Dundr M, Szebeni A. 2000. The nucleolus: an old factory with unexpected capabilities. Trends Cell Biol 10: 189-196. doi:10.1016/S0962-8924(00)01738-4

Ouyang JPT, Folkmann A, Bernard L, Lee C-Y, Seroussi U, Charlesworth AG, Claycomb JM, Seydoux G. 2019. P granules protect RNA interference genes from silencing by
piRNAs. Dev Cell 50: 716-728.e6. doi:10.1016/j.devcel .2019.07.026

Patel A, Lee HO, Jawerth L, Maharana S, Jahnel M, Hein MY, Stoynov S, Mahamid J, Saha S, Franzmann TM, et al. 2015. A liquid-to-solid phase transition of the ALS protein FUS accelerated by disease mutation. Cell 162: 1066-1077. doi:10 $.1016 /$ j.cell.2015.07.047

Pilkington GR, Parker R. 2008. Pat1 contains distinct functional domains that promote P-body assembly and activation of decapping. Mol Cell Biol 28: 1298-1312. doi:10.1128/MCB .00936-07

Pitchiaya S, Mourao MDA, Jalihal AP, Xiao L, Jiang X, Chinnaiyan AM, Schnell S, Walter NG. 2019. Dynamic recruitment of single RNAs to processing bodies depends on RNA functionality. Mol Cell 74: 521-533.e6. doi:10.1016/j.molcel.2019 .03 .001

Prasanth KV, Prasanth SG, Xuan Z, Hearn S, Freier SM, Bennett CF, Zhang MQ, Spector DL. 2005. Regulating gene expression through RNA nuclear retention. Cell 123: 249-263. doi:10 $.1016 /$ j.cell.2005.08.033

Protter DSW, Parker R. 2016. Principles and properties of stress granules. Trends Cell Biol 26: 668-679. doi:10.1016/j.tcb .2016.05.004

Protter DSW, Rao BS, Van Treeck B, Lin Y, Mizoue L, Rosen MK, Parker R. 2018. Intrinsically disordered regions can contribute promiscuous interactions to RNP granule assembly. Cell Rep 22: 1401-1412. doi:10.1016/j.celrep.2018.01.036

Putnam A, Cassani M, Smith J, Seydoux G. 2019. A gel phase promotes condensation of liquid P granules in Caenorhabditis elegans embryos. Nat Struct Mol Biol 26: 220-226. doi:10 .1038/s41594-019-0193-2

Rangan P, DeGennaro M, Jaime-Bustamante K, Coux R-X, Martinho R, Lehmann R. 2009. Temporal and spatial control of germ plasm RNAs. Curr Biol 19: 72-77. doi:10.1016/j.cub .2008.11.066

Raška I, Andrade LEC, Ochs RL, Chan EKL, Chang C-M, Roos G, Tan EM. 1991. Immunological and ultrastructural studies of the nuclear coiled body with autoimmune antibodies. Exp Cell Res 195: 27-37. doi:10.1016/0014-4827(91)90496-H

Saito M, Hess D, Eglinger J, Fritsch AW, Kreysing M, Weinert BT, Choudhary C, Matthias P. 2019. Acetylation of intrinsically disordered regions regulates phase separation. Nat Chem Biol 15: 51-61. doi:10.1038/s41589-018-0180-7

Samir P, Kesavardhana S, Patmore DM, Gingras S, Malireddi RKS, Karki R, Guy CS, Briard B, Place DE, Bhattacharya A, et al. 2019. DDX3X acts as a live-or-die checkpoint in stressed cells by regulating NLRP3 inflammasome. Nature 573: 590-594. doi:10.1038/s41586-019-1551-2

Schaffert N, Hossbach M, Heintzmann R, Achsel T, Lührmann R. 2004. RNAi knockdown of hPrp31 leads to an accumulation of U4/U6 di-snRNPs in Cajal bodies. EMBO J 23: 30003009. doi:10.1038/sj.emboj.7600296

Scheer U, Thiry M, Goessens G. 1993. Structure, function and assembly of the nucleolus. Trends Cell Biol 3: 236-241. doi:10 .1016/0962-8924(93)90123-I

Schwartz DC, Parker R. 1999. Mutations in translation initiation factors lead to increased rates of deadenylation and decapping of mRNAs in Saccharomyces cerevisiae. Mol Cell Biol 19: 5247-5256. doi:10.1128/MCB.19.8.5247

Seydoux G. 2018. The P granules of C. elegans: a genetic model for the study of RNA-protein condensates. J Mol Biol 430: 4702-4710. doi:10.1016/j.jmb.2018.08.007

Shan J, Moran-Jones K, Munro TP, Kidd GJ, Winzor DJ, Hoek KS, Smith R. 2000. Binding of an RNA trafficking response element to heterogeneous nuclear ribonucleoproteins A1 and A2. J Biol Chem 275: 38286-38295. doi:10.1074/jbc .M007642200

Shaw J, Love AJ, Makarova SS, Kalinina NO, Harrison BD, Taliansky ME. 2014. Coilin, the signature protein of Cajal bodies, differentially modulates the interactions of plants with viruses in widely different taxa. Nucleus 5: 85-94. doi:10.4161/nucl.28315 
Sheth U, Parker R. 2003. Decapping and decay of messenger RNA occur in cytoplasmic processing bodies. Science 300: 805-808. doi: $10.1126 /$ science. 1082320

Sheth U, Parker R. 2006. Targeting of aberrant mRNAs to cytoplasmic processing bodies. Cell 125: 1095-1109. doi:10 .1016/j.cell.2006.04.037

Shevtsov SP, Dundr M. 2011. Nucleation of nuclear bodies by RNA. Nat Cell Biol 13: 167-173. doi:10.1038/ncb2157

Sleeman JE, Lamond AI. 1999. Newly assembled snRNPs associate with coiled bodies before speckles, suggesting a nuclear snRNP maturation pathway. Curr Biol 9: 1065-1074. doi:10 .1016/S0960-9822(99)80475-8

Sleeman JE, Trinkle-Mulcahy L, Prescott AR, Ogg SC, Lamond AI. 2003. Cajal body proteins SMN and Coilin show differential dynamic behaviour in vivo. J Cell Sci 116: 2039-2050. doi: $10.1242 /$ jes.00400

Staněk D, Neugebauer KM. 2004. Detection of snRNP assembly intermediates in Cajal bodies by fluorescence resonance energy transfer. J Cell Biol 166: 1015-1025. doi:10.1083/jcb .200405160

Staněk D, Přidalová-Hnilicová J, Novotný I, Huranová M, Blažíková M, Wen X, Sapra AK, Neugebauer KM. 2008. Spliceosomal small nuclear ribonucleoprotein particles repeatedly cycle through Cajal bodies. Mol Biol Cell 19: 2534-2543. doi:10.1091/mbc.e07-12-1259

Taneja KL, McCurrach M, Schalling M, Housman D, Singer RH. 1995. Foci of trinucleotide repeat transcripts in nuclei of myotonic dystrophy cells and tissues. J Cell Biol 128: 995-1002. doi:10.1083/jcb.128.6.995

Tauber D, Tauber G, Khong A, Van Treeck B, Pelletier J, Parker R. 2020. Modulation of RNA condensation by the DEAD-box protein eIF4A. Cell 180: 411-426.e16. doi:10.1016/j.cell .2019 .12 .031

Taylor JP, Brown RHB Jr, Cleveland DW. 2016. Decoding ALS: from genes to mechanism. Nature 539: 197-206. doi:10.1038/ nature20413

Teixeira D, Parker R. 2007. Analysis of P-body assembly in Saccharomyces cerevisiae. Mol Biol Cell 18: 2274-2287. doi:10.1091/mbc.e07-03-0199

Tharun S, He W, Mayes AE, Lennertz P, Beggs JD, Parker R. 2000. Yeast Sm-like proteins function in mRNA decapping and decay. Nature 404: 515-518. doi:10.1038/35006676

Thomson T, Lasko P. 2004. Drosophila tudor is essential for polar granule assembly and pole cell specification, but not for posterior patterning. Genesis 40: 164-170. doi:10.1002/gene .20079

Thomson T, Liu N, Arkov A, Lehmann R, Lasko P. 2008. Isolation of new polar granule components in Drosophila reveals $\mathrm{P}$ body and ER associated proteins. Mech Dev 125: 865-873. doi:10.1016/j.mod.2008.06.005

Thul PJ, Åkesson L, Wiking M, Mahdessian D, Geladaki A, Blal HA, Alm T, Asplund A, Björk L, Breckels LM, et al. 2017. A subcellular map of the human proteome. Science 356: eaal3321. doi:10.1126/science.aal3321

Timchenko LT, Miller JW, Timchenko NA, DeVore DR, Datar KV, Lin L, Roberts R, Caskey CT, Swanson MS. 1996. Identification of a (CUG)n triplet repeat RNA-binding protein and its expression in myotonic dystrophy. Nucleic Acids Res 24: 4407-4414. doi:10.1093/nar/24.22.4407

Tourrière H, Chebli K, Zekri L, Courselaud B, Blanchard JM, Bertrand E, Tazi J. 2003. The RasGAP-associated endoribonuclease G3BP assembles stress granules. J Cell Biol 160: 823-831. doi:10.1083/jcb.200212128

Trcek T, Lehmann R. 2019. Germ granules in Drosophila. Traffic 20: 650-660. doi:10.1111/tra.12674

Trinkle-Mulcahy L, Sleeman JE. 2017. The Cajal body and the nucleolus: "In a relationship" or "It's complicated"? RNA Biol 14: 739-751. doi:10.1080/15476286.2016.1236169
Tsai W-C, Gayatri S, Reineke LC, Sbardella G, Bedford MT, Lloyd RE. 2016. Arginine demethylation of G3BP1 promotes stress granule assembly. J Biol Chem 291: 22671-22685. doi:10.1074/jbc.M116.739573

Van Treeck B, Parker R. 2018. Emerging roles for intermolecular RNA-RNA interactions in RNP assemblies. Cell 174: 791802. doi:10.1016/j.cell.2018.07.023

Van Treeck B, Protter DSW, Matheny T, Khong A, Link CD, Parker R. 2018. RNA self-assembly contributes to stress granule formation and defining the stress granule transcriptome. Proc Natl Acad Sci 115: 2734-2739. doi:10.1073/pnas .1800038115

Vanzo N, Oprins A, Xanthakis D, Ephrussi A, Rabouille C. 2007. Stimulation of endocytosis and actin dynamics by oskar polarizes the Drosophila oocyte. Dev Cell 12: 543-555. doi:10 $.1016 /$ j.devcel.2007.03.002

Verheggen C, Lafontaine DLJ, Samarsky D, Mouaikel J, Blanchard J-M, Bordonné R, Bertrand E. 2002. Mammalian and yeast U3 snoRNPs are matured in specific and related nuclear compartments. EMBO J 21: 2736-2745. doi:10.1093/emboj/ 21.11.2736

Vogler TO, Wheeler JR, Nguyen ED, Hughes MP, Britson KA, Lester E, Rao B, Betta ND, Whitney ON, Ewachiw TE, et al. 2018. TDP-43 and RNA form amyloid-like myo-granules in regenerating muscle. Nature 563: 508-513. doi:10.1038/ s41586-018-0665-2

Voronina E, Seydoux G, Sassone-Corsi P, Nagamori I. 2011. RNA granules in germ cells. Cold Spring Harb Perspect Biol 3: a00274. doi:10.1101/cshperspect.a002774

Voronina E, Paix A, Seydoux G. 2012. The P granule component PGL-1 promotes the localization and silencing activity of the PUF protein FBF-2 in germline stem cells. Development 139: 3732-3740. doi:10.1242/dev.083980

Walker MP, Tian L, Matera AG. 2009. Reduced viability, fertility and fecundity in mice lacking the Cajal body marker protein, coilin. PLoS One 4: e6171. doi:10.1371/journal.pone .0006171

Wang JT, Seydoux G. 2014. P granules. Curr Biol 24: R637R638. doi:10.1016/j.cub.2014.06.018

Wang J, Pegoraro E, Menegazzo E, Gennarelli M, Hoop RC, Angelini C, Hoffman EP. 1995. Myotonic dystrophy: evidence for a possible dominant-negative RNA mutation. Hum Mol Genet 4: 599-606. doi:10.1093/hmg/4.4.599

Weihl CC, Temiz P, Miller SE, Watts G, Smith C, Forman M, Hanson PI, Kimonis V, Pestronk A. 2008. TDP-43 accumulation in IBM muscle suggests a common pathogenic mechanism with frontotemporal dementia. J Neurol Neurosurg Psychiatry 79: 1186-1189. doi:10.1136/jnnp.2007.131334

Wheeler JR, Matheny T, Jain S, Abrisch R, Parker R. 2016. Distinct stages in stress granule assembly and disassembly. Elife 5: e18413. doi:10.7554/eLife.18413

Wheeler JR, Jain S, Khong A, Parker R. 2017. Isolation of yeast and mammalian stress granule cores. Methods San Diego Calif 126: 12-17. doi:10.1016/j.ymeth.2017.04.020

Wolozin B, Ivanov P. 2019. Stress granules and neurodegeneration. Nat Rev Neurosci 20: 649-666. doi:10.1038/s41583019-0222-5

Xing W, Muhlrad D, Parker R, Rosen MK. 2020. A quantitative inventory of yeast $\mathrm{P}$ body proteins reveals principles of composition and specificity. BioRxiv doi:10.1101/489658

Yasuzumi G, Sawada T, Sugihara R, Kiriyama M, Sugioka M. 1958. Electron microscope researches on the ultrastructure of nucleoli in animal tissues. Z Zellforsch Mikrosk Anat Vienna Austria 1948: 10-23. doi:10.1007/BF00496710

Youn J-Y, Dunham WH, Hong SJ, Knight JDR, Bashkurov M, Chen GI, Bagci H, Rathod B, MacLeod G, Eng SWM, et al. 2018. High-density proximity mapping reveals the subcellular organization of mRNA-associated granules and bodies. Mol Cell 69: 517-532.e11. doi:10.1016/j.molcel.2017.12.020 


\section{$\$_{\text {CSH\& }}^{\infty}$ Cold Spring Harbor Symposia SYMPOSIA on Quantitative Biology}

\section{RNP Granule Formation: Lessons from P-Bodies and Stress Granules}

Giulia Ada Corbet and Roy Parker

Cold Spring Harb Symp Quant Biol published online June 1, 2020

Access the most recent version at doi:10.1101/sqb.2019.84.040329

$\mathbf{P}<\mathbf{P} \quad$ Published online June 1, 2020 in advance of the print journal.

Creative This article is distributed under the terms of the

Commons http://creativecommons.org/licenses/by-nc/4.0/, which permits reuse and

License redistribution, except for commercial purposes, provided that the original author and source are credited.

Email Alerting Receive free email alerts when new articles cite this article - sign up in Service the box at the top right corner of the article or click here.

Advance online articles have been peer reviewed and accepted for publication but have not yet appeared in the paper journal (edited, typeset versions may be posted when available prior to final publication). Advance online articles are citable and establish publication priority; they are indexed by PubMed from initial publication. Citations to Advance online articles must include the digital object identifier (DOIs) and date of initial publication.

To subscribe to Cold Spring Harbor Symposia on Quantitative Biology go to: http://symposium.cshlp.org/subscriptions 